Board member development in the public, voluntary and social housing sectors

European Journal of Training and Development (2012), Vol. 36, No. 6, pp. 630-645.

\author{
Carolyn Ward \\ Senior Lecturer in Leadership and HRM \\ Teesside University Business School \\ Teesside University \\ Middlesbrough \\ UK \\ + 44 (0) 1642342881 \\ C.Ward@tees.ac.uk (Corresponding author)
}

David Preece

Professor of Technology Management \& Organization Studies

Teesside University Business School

Teesside University

Middlesbrough

UK

D.Preece@tees.ac.uk 
Board member development in the public, voluntary and social housing sectors

\begin{abstract}
Purpose

Given a number of recent and ongoing changes to the role and responsibilities of executive and non-executive Board members of UK social housing organizations, the paper offers a literature review which explores the development provision for Board members within such organizations. Our key question is: 'How are executive and nonexecutive Board members being prepared for these changes?'

Design/methodology/approach

A systematic literature review was undertaken, based upon the main business and management databases. This was followed by a thematic analysis to uncover what we know about executive and non-executive Board member training and development within the public and voluntary sectors, in particular within UK social housing organizations. Findings

Despite the increasingly important role of Boards in the not-for-profit sector, we found only a limited number of publications focusing on HRD issues. The literature did provide some insight into the HRD experiences of executive and non-executive Board members. The majority of papers centred on leadership and governance matters, mainly Board effectiveness, performance and 'Board capital', rather than human capital. In so far as Board member development is discussed, it is mainly in relation to their recruitment to the Board and the sort of skills required, with little attention given to matters such as succession planning and member development.

\section{Research limitations/implications}

Given the limited extent of research to date into executive and non-executive Board development in social housing organizations, it follows that we have limited knowledge of what is-or is not- happening in practice. This highlights the need for more empirical research, on the basis of which it should be possible to offer suggestions for changes to/ improvements in Board member development activities.

Originality/value

The paper reviews the current state of our knowledge relating to executive and nonexecutive Board member development in not-for-profit and social housing organizations.

\section{Keywords}

Leadership development, executive development, non-executive development, social housing organizations, Boards/ governance.

\section{Paper type}

Conceptual
\end{abstract}




\section{Introduction}

As is well-known and established, public service provision in the UK is experiencing continued change and uncertainty. The major reduction in government income/grants has generated a search for new ways of working, and this has lead to efforts to change or overhaul ownership, governance, managerial, leadership, structural, financial and regulatory regimes. At the same time, and as a result of these changes, social housing provision in the UK has experienced major reform, including privatisation (Malpass, 2000; Walker, 2001; Gruis and Nieboer, 2003, Ginsberg; 2005, Mooney and Poole, 2005). Social housing associations (SHAs) have emerged and developed from the transfer of local authority homes, tenants and employees to new forms of organization, now generically termed Registered Social Landlords (RSLs). Given also the imminent (further) changes to SHAs' regulatory and governance framework as a result of the review by the Department for Communities and Local Government (DCLG, 2010), it is timely to study a key SHA group- non-executive board members (NEBMs).

Our focus here is upon the training and development activities of executive and NEBMs, given especially that many of these SHAs have 'relatively inexperienced boards and senior management teams' (Pawson and Mullins, 2010: 4). There is currently a limited amount of research on the activities of executives/ leaders and managers in UK social housing (Czischke, 2009; Ward et al., 2010) in general, and in relation to HRM/ HRD in particular, with Casey (2008) labelling it a 'cinderella profession'. Commentators have identified evolving complexity in the sector and a gradual move towards residualisation and polarization (see, for example, Forrest and Murie, 2011). The result has been more commercially focused organizations and an enhanced prominence in their locales (Oxley et al., 2010). It is argued that the new 'social landlords' are more innovative than when housing organizations were under local authority ownership/ control, and that they display 'social business' traits (Collier, 2005). Performance management systems, employee recruitment, development and retention strategies, etc, have often been replicated from the private sector in the transition process (Kirkpatrick et al., 2005; Pollitt, 2000; Sprigings, 2002; Walker, 2001). The social housing sector today faces a number of challenges (Pawson and Mullins, 2010; Preece and Ward, 2012; Ward 
and Preece, 2010a; 2010c), and in this context it seems to us to be important to explore the evolving nature of leadership and leadership development in the sector (Ward and Preece, 2010b; Ward et al, 2010d), and in particular the (changing) role and development of non-executive board members, who, at least in principle, have been accorded a more central place in SH organization governance, given the perceived need for a broader range of expertise and representation in these uncertain times.

Studies of executive Boards have to date been mainly in the private sector and have focused upon leadership and governance issues (Brown, 2007; Jackson et al., 2003;McNulty and Pettigrew,1999; Pye,2001), and especially the role and relationship of the CEO with the board or the chair members of the Board (Boyd, et al.,2010; Dey et al.,2011;Reid and Turbide,2012). This reflects a focus upon the Board as a whole ('Board capital') as opposed to individual board members (human capital). Certain challenges are faced in attempting to research non-execs: gaining access can be difficult; their development activities appear to be informal and ad-hoc in nature (Dalziel, 2010; Vicere and Graham, 2002), and there appears to be a belief that when individuals have reached this level they have acquired all the relevant experience and learning needed to carry out the role effectively. Researchers studying governance in the third sector are presented with the challenge of studying 'multi-faceted governance' structures (Cornforth, 2002; McDermont, 2007).

In our view, executive and non-executive development is an important area of study for the training and development field for a number of reasons (discussed in more detail later in the paper), due not least to the fact that the performance and effectiveness of Boards has come under detailed scrutiny following corporate scandals. Cornforth (2001) talking about the not-for-profit sector, stresses the need for assessments to take place that would gauge both the skills needed along with board composition as well as systems to promote the recruitment and training for new board members. Until these major scandals and thus more recent times, there appears to have been a more general assumption that individuals acquired executive Board positions on the basis of their previous experience and status, with the implicit assumption that they possessed the necessary skills, training and education. Moreover, the Tyson review of 2003, in discussing executives and HRD, has argued that there is a lack of sufficient suitable 
individuals, with the talent pool ever decreasing, implying that new HRD strategies have to be tested and adopted. People in Board positions now experience greater accountability and scrutiny and the need to display greater transparency. This has some important implications for HRD practice and practitioners, which are explored later in the paper.

The key questions addressed in the paper are: what, if any, training and development do executive and non-executive Board members receive, and how does this contribute to the effective carrying out of their role, given especially the major contextual changes which have been and are taking place in the sector? The rest of the paper is structured as follows: firstly we present an outline of SHAs in the UK with particular respect to NEBMs; secondly, the cognizant literature is reviewed; and lastly the discussion and conclusions section outlines the implications of our review and findings for HRD theory and practice.

\section{The changing context of UK social housing and the Board member}

Social housing provision in the UK has until recently been undertaken by the municipal council departments which owned the houses, and where their main functions were to collect rents, carry out repairs and administer housing benefits. It was primarily about the allocation of empty properties (housing stock) within a given local authority boundary to those within society deemed to be 'in housing need'. Today the landscape is a very different one, with large numbers of not-for- profit organizations operating partially or wholly separately from local authority control, covering national boundaries and delivering an array of additional services, including the provision of job and training opportunities for tenants and access to affordable childcare (see Ward and Preece, 2010b, for an outline of the challenges these new organizations are facing, and the implications for HRM and HRD). These new social housing providers have been referred to as 'social businesses'(Collier, 2005), and they operate alongside traditional 'philanthropic' housing associations and the dwindling number of local authority providers.

The delivery and management of social housing has had a chequered history, and training and development provision has been limited overall. In the 1980s, when social housing was provided by local authorities: 
Most housing department staff received little training and few were professionally qualified. Rather, new staff were typically "shown the ropes" by longer serving officers [with the result that] attitudes and behaviour [were] handed down from one generation to another with little thought about the wider implications of particular activities and action (Merrett, 1979:208; see also Pawson and Mullins,2010).

An initial major impetus to change over the last twenty years or so was the introduction of private sector funding in the early 1990s (see Ward and Preece, 2010a, b, c for a discussion of subsequent sectoral changes and developments). In April 2012, the government introduced self-regulation into social housing organizations with the disbanding of the social housing regulation body, The Tenancy Services Authority. This seems likely to alter the paternalistic relationship between Board members and CEOs to one with a greater strategic focus and emphasis on organization and Board performance (Inside Housing, 3 February 2012). The new statutory regulations require NEBMs to facilitate the new governance and regulatory requirements. Commentators are undecided as to whether SHAs are operating in the public and/ or private sectors (Inside Housing, 13 January 2012) with some terming the transferred local authority housing departments as 'quasi-private', whilst the traditional charitable housing associations navigate towards the voluntary sector- the 'voluntary housing movement'. In view of this, Myers refers to the UK voluntary sector as a 'mass of micro, small, medium, large and extra large organisations' (2004: 639). Jackson (2010), whilst considering the needs of this 'third sector', identifies a lack of professional skills and Maddock (2002) specifically identifies a lack of leadership skills.

With regard to governance matters, Jones and Pollitt (2004) comment that the Cadbury Report (1992) not only changed perceptions of the Board of Directors, but also stressed the importance of a separation of duties and the role of the independent nonexecutive director. NEBMs in SHAs, by definition, are acting at a corporate/strategic leadership level, but they have part-time, voluntary and usually unpaid positions, and serve for a maximum term of three years, renewable up to a maximum of nine years. SHA Boards are required to have four clearly defined roles: Chair and Independent, 
Council- nominated and Tenant representatives. As Flint (2004) has noted, research is needed into how the transformation of the tenant role and responsibilities is being met by SHAs. This should address, inter alia, the recruitment and subsequent training and development of these tenants, who are both a service consumer and 'influencer'. According to Gibson (2008: 64), the SHA Board must: 'Be both well informed....and contribute specialist knowledge/expertise and/or relevant experience of customers, neighbourhood issues, etc.' and 'contribute to creating and sustaining the "Learning Board" by participation in, or leading, Board induction and development activities'. Core to the foregoing is staff and organization performance (Korac-Kakabadse et al., 2001; Kakabadse et al., 2002; Brown, 2007). It would seem unlikely that this can be addressed without the parallel development of senior management and executives (Suutari and Viitala, 2008).

\section{Methodology}

The systematic literature review had two main aims: to uncover what had been published on the training and development of executive and NEBMs in the public and voluntary sectors and the social housing sector in particular. The specific stages were as follows:

\section{Identification of key words and phrases}

The authors initially experimented with alternative ways of expressing the key terms to be explored. These included 'non executive director training'; 'non executive development'; 'non executive board development', 'board capacity', and 'non executive committee training', the latter to capture terminology commonly used within social housing organizations.

\section{The creation of 'search strings'}

Social housing organizations operate across and within a number of 'sectors', as highlighted in the introduction. In view of this, a number of search strings were identified covering the following: 'public sector'; 'voluntary sector'; 'non- profit'; 'social housing' and 'social enterprise'.

\section{Resources}


Given that social housing research is located predominantly within the social sciences domain and that there is a cross- over into social policy and health related fields (Kirkpatrick et al., 2005), a wide search was undertaken in an effort to ensure the inclusion of all key resources. The following databases were utilized: EBSCO, EMERALD, Science Direct, SCOPUS, Web of Knowledge (ISI), and (to capture the health and social care field) ASSIA. In addition to the above academic journal databases, other resources utilized included:

- professional web sites covering social housing, that is, The Chartered Institute of Housing weekly magazine (which goes to over 20,000 housing professionals world-wide) and that of the National Housing Federation (NHF).

- Books and reports cited in the literature.

\section{Filtering the results}

'Limitators' were placed on the search in order to achieve specific focus, reduce the number of publications to a manageable number, and reliability-we therefore restricted ourselves to peer- reviewed journals and publications in the English language. In an iterative process, some search strings were modified- for example 'public sector' to 'public sector organis/zations'. Finally, the abstracts were read in order to identify the focus of each publication and hence isolate those which would be read in full. The selected publications were then categorized into two areas: training and development of Board members in a) the public and voluntary sectors (but excluding social housing), and b) in social housing organizations. The presentation of our findings below is structured according to this distinction.

\section{Findings}

Board member training and development in the public and voluntary sectors By way of introduction, it is important to note that two particular reports (Higgs, 2003 and Walker, 2009) devote some attention to the training and development of nonexecutive directors (NEDs); however, they are primarily based on and addressed to the private sector. Corporate scandals have lead to calls for the training and development of 
Board members, and the creation of effective boards has been a key theme in a number of articles and reports, for example recruiting people with the requisite skills and the associated induction training (Alban-Metcalfe,2010;Cornforth,2001;Mason and Royce,2007), changing the composition and structure of boards by increasing Board diversity (Cornforth,2002;Dulewicz and Herbert,2004;Huse et al., 2009), and nurturing the relationship between the CEO and Board members/chairs (Cornforth,2004).

The findings which emerged from our systematic literature review of the public and voluntary sectors literatures highlighted local governance and community sustainability issues in a number of studies (see, for example, Mawson, 2010; Smith, 2010). Particular interest here centres on the 'uniqueness' of the 'third sector', and how it has adopted and adapted HRM/D policies and practices from the private sector in order to respond to the challenges it faces (see, for example, Hay et al., 2001). Some studies address the recruitment of Board members (for example Van der Walt et al., 2006 in a New Zealand setting), while others discuss the use of 'tried and tested' recruitment techniques to attract Chairs to the sector (see, for example, Alban-Metcalfe et al., 2010). As Hough (2006: 373) remarks, the dominant methodology in researching "what is happening inside the black box" is a positivist approach based on interviews relating to the principal-agent theory.

The governance, communication, organizational, etc approach adopted by the Board Chair is often viewed as pivotal for Board effectiveness. Training for the Chair role is explored by Dulewicz and Taylor (2007). They review the use of coaches and succession planning, drawing upon their research into a 'Non-Executive Director Award' scheme (which included a separate category for not-for-profit and public organizations). They stress the need for Chairs to have up- to- date and relevant knowledge, noting that one way of achieving this is through ongoing training. They recommend that external facilitators/ consultants with an HR background are deployed in a variety of support and developmental roles, including performance appraisals of Board members. It is also recommended that specialists rather than generalists are used in recruitment and selection.

Brown (2007) notes that few studies have been undertaken on Board development per se, which he defines as 'the range of activities related to building and maintaining a 
strong board of directors. This includes recruiting and selecting, training and preparing, monitoring performance, and removing board members' (2007:303). In his discussion of Board member performance assessment he draws on a range of literatures, including nonprofit Board governance, corporate governance and volunteer management (see also Preston and Brown, 2004). He draws two main conclusions: (i) no universal criteria exist for the appropriate competencies of a non-profit Board member; (ii) there is a distinct lack of individual board member performance indicators (BMPIs). Preston and Brown (2004) do offer BMPIs, but, as Brown (2007) comments, they are crude measures, such as attendance figures and contribution to meetings. Brown highlights the benefits of Board induction (as does Cornforth, 2001 and Long, 2008), along with the facilitation of leadership succession, based upon an assessment of leadership and development needs via methods such as coaching and mentoring. Nonetheless, his findings demonstrated that only a limited amount of such evaluation takes place.

With respect to the measurement of Board effectiveness, several papers were found, predominantly from the US. Gill et al (2005) produced a 'Governance SelfAssessment Checklist', which has a number of subscales, two of particular relevance here are: Human Resource Stewardship and Board Development. The latter is defined as 'Assessing practices relating to the recruitment and induction, team building and board self-assessment' (2005: 287). The latter was rated the lowest by Boards and therefore as the area that requires the most improvement. The authors comment: 'Board Development, which is directly related to the issue of improving board effectiveness, was especially weak'. (2005: 287).

In an earlier three- year study, again from the US, Holland and Jackson (1998) compared Boards' performance with respect to those which received developmental interventions (such as coaching and teaching) as against those which did not. Six aspects of Board competency were measured in relation to effective governance. The results showed that those Boards which had received developmental support over a three year period improved their performance. They noted however that the financial cost of duplicating these interventions as a normal working practice would be highly impractical. Chait et al (2005), however, note the poor results derived from Board training interventions. 
In their case study analysis, Jackson et al (2003) reflect upon 'executive development' (which they define as encompassing CEO, Chair, executive director and non-executive director roles), and discuss both individual and collective development methods. They distinguish between planned and unplanned approaches, and found that most developmental activities were ad-hoc and informal (see also Dalziel, 2010). Other writers (notably Cornforth,2001) note a lack of evaluation of developmental activities, as well as the 'mixed and questionable results' from studies of Board effectiveness (Hough,2006).

Holland and Jackson (1998) found the barriers to effective board performance were 'ambiguous expectations, weak accountability, lack of clarity about what needs changing, biases from previous unsuccessful efforts at change, and discomforts from relinquishing familiar practices and trying new ones' (1998:129). In a more recent study Jackson et al (2003), from their case studies, support the claim of Pierce (2001) that lack of time often contributes to the lack of learning and development at this level. This raises the possibility of potential organizational 'resistance' and 'cultural divides', which are yet to be systematically explored in public and voluntary sector research.

To summarize, the literature is dominated by papers on the measurement and categorization of Board effectiveness and outlines of and/ or findings relating to Board competencies. The call is for enhanced Board effectiveness, and in most cases it is argued that this can and should be achieved through the recruitment of people with the appropriate skills and knowledge, with less emphasis placed upon the intraorganizational development of the necessary skills and knowledge. It would appear that training and development for Board members is considered less important than recruiting the 'right' people. With this in mind, we now turn to present our findings regarding Board member training and development in the social housing sector.

\section{Board member training and development in social housing organizations}

We were unable to identify any academic journal publications addressing this matter, however there are a few government and sectoral reports and practitioner publications which we have been able to draw upon. An Audit Commission report of 2003 reviewed 
the first eight 'Arms Length Management Organizations' (ALMOs) which were transferred from local authorities, and observed that:

The quality of the board of directors is crucial to delivering excellent services. The director's role involves managing conflicting priorities and board members should be given ongoing training opportunities and support to help them to make a sustained contribution to improving services (2003:12).

The role and composition of the ALMO Boards was discussed and it was noted that some of them lacked the relevant expertise, especially in finance. The report stated that every Board member must "perform elements of each of the different roles [stewardship, strategic/managerial and democratic] and they must acquire the skills to enable them to perform at their best' (2003:13). The review also reported that some ALMOs were experiencing recruitment problems, particularly with regard to the independent members who were required to have expert financial knowledge. It stated that 'training and development is important for all board members, both to develop people's skills where required and to help the board work well as a unit' (2003:17). ALMOs experiencing problems were recommended to adopt a number of initiatives, including taking a longerterm view, the introduction of succession planning, and to draw upon extant committees and groups as a 'talent pool' for vacancies on the main Board.

A report commissioned by The Centre for Market and Public Organisations (Cowan et al., 2006) included a social housing case study, where the roles of the members of the governing Boards were scrutinized. A number of Board members were interviewed regarding such matters as their reasons for becoming Board members; a limited amount of information is provided on Board recruitment and retention.

Two survey reports commissioned by the Chartered Institute of Housing (CIH) in 2011 and 2012 (Inside Housing, 4 February 2011 and 3 February 2012) detail the growing significance and changing role of social housing organization Board members. They found that most Board members were unpaid, part- time volunteers, who were nonetheless given more responsibility for financial and risk management. The 2011 report highlights the differing perceptions of CEOs and the other Board members of 
Board performance, effectiveness and its responsiveness to future challenges. There is reference to a need for the ongoing development of Board members through 'ongoing board member education'. A 2012 governance audit commissioned by the CIH confirmed this, identifying Board skill gaps and the need for member training and development, not least in the light of the anticipated statutory requirement for self- regulation (discussed earlier). The Board members and CEOs were asked whether they believed the SHA Boards were ready for the changes and challenges ahead and whether they were happy with the effectiveness of the Boards and the skills mix of members. Just $15 \%$ of CEOs said 'yes' to the latter question. Responses differed according to SHA size, with the smaller and medium- sized organizations showing less optimism concerning their Boards' achievements and effectiveness. There was recognition of the need for a shift of many Boards from an outdated, volunteer-based ethos, towards a much stronger commercial focus, and an associated need for changes in working practices.

Our literature review findings, then, may be summarized as follows:

(1) The majority of publications discuss matters relating to Board structure, governance, composition, performance, and effectiveness

(2) There is a limited amount of material relating to the members of Boards per se

(3) In so far as HRM/D issues are addressed, this is mainly with respect to diversity and recruitment

(4) There would appear to be some cultural barriers to the introduction and spread of training and development for Board members

(5) The social housing sector is under- researched from an HRD perspective, not least with respect to Boards and NEBMS. This is of concern, especially given the introduction of self-regulation in the sector.

With respect to SHA Board members in particular, it seems safe to say that many are insufficiently strategic and forward thinking, and that there is a need for Board member knowledge and skills to be strengthened (interestingly, but worryingly, the above reports do not say how this might be achieved). The reports place a good deal of emphasis upon the skills individuals might bring to the Board, and insufficient in our view upon how 
members might come to create cohesive Board teams and develop themselves and the Board. It is also important to note that only $21 \%$ of Board chairs are female and also that only $21 \%$ of Boards' chief executives are female (Inside Housing, 11 February 2011). This clearly points to the need, inter alia, for HRM/D specialists who are involved in the recruitment and development of Board members to explore the means by which they might attract and appoint more females.

To the best of our knowledge, the only social housing NEBM programme currently operating in the UK which systematically addresses such issues as succession planning and Board member development is a university-organization partnership between Trent and Dove Housing Association and Derby University, which commenced in 2008. Here, people in the organization who are interested in becoming a Board member can take such modules as: 'The role of the Board member', 'The workings of Housing Associations', 'Monitoring performance', and 'Equality and diversity'. As at January 2009, nearly 20 Housing Associations had taken part in the programme, and the National Housing Federation is considering making it a standard provision for all HAs in the UK (Inside Housing, 16 January 2009). This signals an emerging shift from informal, ad hoc developmental activities to more formal, group-based provision.

\section{Discussion: implications for executive Board member development in SHAs} Crossan et al (2011) argue that the directors and committee members of not-for-profit organizations form the organization's back-bone, where 'often their experience, knowledge and social interests, in addition to their composition and collaboration as a group can have a significant impact on the social and economic direction, motivation and behavior of not-for-profit organizations' (2011: 665). Accepting that this is true, why, then, do we not know more about what exactly they do and how they step into the role and develop subsequently? There follow some possibilities.

(1) The focus in practice has been upon the recruitment of Board members, with an emphasis upon recruiting for 'immediate performance' as opposed to the medium and longer-term development of these people for the emerging future. Given this, there may 
be a limited talent pool of suitable people for the sector as it has developed. Hence, urgent consideration needs to be given to addressing this lacunae.

(2) Recent reports and surveys have demonstrated the need for the on-going training, education and development of executive and NEBMs to address the skills/ competency gap. Thus, HRD specialists need to identify the emerging required skills and competencies, as well as more effective ways in which they can be acquired by Board members, both individually and as a team. There are constraints, of course, and particularly for NEBMs, given their limited opportunities for 'on-the job' learning, given also that they are part-time, volunteers, and unpaid, and required to attend only a handful of meetings per year. On the other hand, perhaps they have more time for 'off-the-job' training and development?

(3) Experience alone is increasingly no longer sufficient preparation for becoming an effective Board member in today's complex and ever- changing environment. What is more, if we rely on experience alone, then we are in danger of marginalizing less experienced (and perhaps younger) people who may have a good deal to offer, given timely and appropriate training and development. A similar point can be made in relation to gender and diversity.

(4) The more traditional modes of training and development are somewhat problematic when applied to executive board development, and hence alternatives need to be explored and considered (see, eg, Iles and Preece, 2006; Preece and Iles, 2009). Given the lack of experience of many present SHA Board members in coaching and mentoring and the lack of appropriate role models for today's turbulent times, this is likely to pose challenges for HRD. Also, in relation to performance management, how might NEBMs get feedback on their performance?

(5) Given that the majority of NEBMs in SHAs are currently unpaid part-time volunteers, how are they to be supported and developed, bearing in mind that the organizations are expecting them to help align organizational strategies with the changing business 
environment? The message from the $\mathrm{CIH}$ is that voluntarism is soon to become a phenomenon of the past (Inside Housing, 3 February 2012). How might HRM/HRD specialists help manage this transition?

(6) Does Talent Management have something to offer here? Recruiting and retaining talented executive and non-executive Board members poses challenges for HRM and HRD professionals. Drawing upon Iles et al (2010), decisions would need to be made whether to adopt an 'exclusive-positions' or 'exclusive-people' talent management strategy, whilst the two 'inclusive' alternatives would seem to be ruled out by definition. The 'talent pool' of NEBMs may be particularly small within SHAs, although, as with a number of issues we are considering here, we don't really know, as we do not have the requisite empirical research. Traditional methods of succession planning are problematic, for example, when recruiting a tenant representative from the community. The implication of all this is that HRD/M specialists will need to be innovative in their approach to recruiting and nurturing external people into Board roles.

In summary terms, a number of HRD dilemmas, questions and alternatives are posed with regard to the development of SHA executives and non-executives in the context of these changing times. As Jackson et al (2003: 250) have observed: 'context is crucial: generic executive skills and competencies exist, but executive capability involves putting these skills and competencies into action in a unique manner that adds value to the organization'.

\section{Conclusion}

The SHA sector in the UK is continuing to grow as is the number of executive and nonexecutive Board members; indeed some SHAs have already experienced a second phase of restructuring (post-separation from their local authorities) through changes in ownership, organization restructuring, union organization (see Preece and Ward, 2012), regulatory changes, etc. The discussion above relating to our findings on executive and non- executive Board member development in SHAs raises many more questions than we have answers, for, as has become clear, we lack sufficient solid, up-to-date, researchbased data at the level of practice on such matters as the use of competency frameworks, 
appraisal and performance monitoring, and initial and on-going executive development. This is another area where research into Board practice is required.

The assessment and study of the performance of Boards and their members is clearly a central requirement for identifying and earmarking the means to close key skills and knowledge gaps and for aligning them to the organisation's objectives and strategy. To take a key example, the fulcrum of required Board expertise in social housing organizations has shifted towards finance and strategy, and we suspect that by no means all Board members are able to fully comprehend detailed financial statements and data.

How are SHAs to recruit and retain talented tenant representatives in the future from the communites in which they are located? What lessons can be drawn from past succession planning policies and practices, and can they be applied to NEBMs entering from outside the organization? Can talent management be adopted within SHAs to address some at least of the challenges referred to above, and if so, how?

The above questions lead one into an agenda for future research: empirical, theoretically-informed research is needed into a range of HRD and HRM issues relating to SHA executive and non-executive Board member skills, knowledge, experience and practices, including their recruitment, selection, induction and ongoing training and development. In addition, it is important to know which HRD programmes have been introduced into these organizations and which are planned for present and aspiring Board members, given the sort of significant contextual changes we have outlined above. Such knowledge would inform, inter alia, an assessment of the extent to which executives and NEBMs have been equipped with the knowledge, skills and competences they need to contribute to the future direction and sustainability of their organizations.

\section{Acknowledgements}

We would like to thank the Editor and reviewers for their most helpful and constructive feedback.

\section{REFERENCES}

Alban-Metcalfe, J., Alimo-Metcalfe, B. and Hughes, M. (2010),"Selection of chairs of primary care trusts: Evidence of reliability and validity", Journal of Health Organization and Management, Vol. 24, No.1, pp.57 - 99. 
Audit Commission (2003) Learning from the ALMO's : Housing National Report.

Available at www.audit-

commission.gov.uk/nationalstudies/housing/Pages/learningfromthefirsthousingalmos.asp

x. (accessed 26 February 2012)

Boyd, B., Haynes, K. and Zona, F. (2010), "Dimensions of CEO-Board Relations", Journal of Management Studies, Vol.48, No. 8, pp.1892-1923.

Brown, W. (2007), "Board Development Practices and Competent Board Members: Implications for Performance", Non-Profit Management and Leadership, Vol.17, No. 3, pp. 301-317.

Casey, R. (2008), “On Becoming a Social Housing Manager: Work Identities in an Invisible Occupation", Housing Studies, Vol.23, No. 5, pp.761-780.

Chait, P., Ryan,W. and Taylor, B. (2005), Governance as Leadership: Reframing the Work of Nonprofit Boards, Wiley, New York.

Collier, P. (2005), "Governance and the quasi-public organization: a case study of social housing”, Critical Perspectives on Accounting, Vol.16, No.7,pp. 929-949.

Committee on the Financial Aspects of Corporate Governance (The Cadbury Report) (1992) Report of the Committee on the Financial Aspects of Corporate Governance, London, Gee Publishing.

Cornforth, C. (2001), "What Makes Boards Effective? An Examination of the Relationships Between Board Inputs, Structure, processes and Effectiveness on NonProfit Organizations," Corporate Governance: An International Review, Vol.9, No.3,pp. 217-227.

Cornforth, C. (2002), "Introduction: the changing context of governance - emerging issues and paradoxes", in Cornforth, C. (ed.) The Governance of Public and Non-profit Organizations: what do boards do?, Routledge, London.

Cornforth, C. (2004)," The Governance of co-operatives and mutual associations: a paradox perspective", Annals of Public and Co-operative Economics, Vol.75 No. 1,pp. 11-32. Available at http://dx.doi.org/doi:10.1111/j.1467-8292.2004.00241.x (accessed 9 March 2012)

Cowan, D., McDermot, M. and Prendergast, J. (2006), "Governing and Governance: A Social Housing Study", The Centre for Market and Public Organisations. Working Paper No. 06/149.

Crossan, D., Ibbotson, P. and Bell, J. (2011) " The hologram effect in entrepreneurial 'social commercial' enterprises," Journal of Small Business and Enterprise Development, Vol.18, No.4, pp.655- 672 . 
Czischke, D. (2009), "Managing Social Rental Housing in the EU: A Comparative Study", European Journal of Housing Policy, Vol. 9, No. 2, pp. 121-151.

Dalziel, M. (2010), "Strategies for Leadership and Executive Development", in Gold, J., Thorpe, R. and Mumford, A.(Eds.) The Gower Handbook of Leadership and Management Development, Gower, London. pp. 99-117.

DCLG (2010) Review of social housing regulation Department for Communities and Local Government. Available at www.communities.gov.uk/documents/housing/pdf/1742903.pdf (accessed 3 March 2012)

Dey, A., Engel, E. and Liu, X. (2011), "CEO and board chair roles: To split or not to split?”, Journal of Corporate Finance, Vol. 17, No.5, pp. 1595-1618.

Dulewicz, V. and Herbert, P.(2004), "Does the composition and practice of boards of directors bear any relationship to the performance of their companies ?" Corporate Governance: An International Review, Vol. 12, No. 3, pp. 263 - 280.

Dulewicz, V, Gay, K. and Taylor, B. (2007),'What makes an outstanding board chairman: Findings from the UK Non-Executive Director of the Year Awards, 2006, Corporate Governance: An International Review,Vol.15 No.6, pp. 1056-1069.

Dulewicz,V. and Taylor, B.(2010) “Lighting the way ahead”, People Management, 14 January, pp. 24-7.

Flint, J.(2004), “ The Responsible Tenant: Housing Governance and the Politics of Behaviour", Housing Studies, Vol. 19, No. 6, pp.893-909.

Forrest, R. and Murie, A. (2011), Selling the Welfare State: The Privatisation of Public Housing, Routledge, Abingdon.

Gibson, A. (2008), Achieving Excellence: Board Appraisal. National Housing Federation.

Gill, M., Flynn, R. and Reissing, E. (2005), “The Governance Self-Assessment Checklist: An Instrument for Assessing Board Effectiveness," Nonprofit Management and Leadership, Vol.15, No.3, pp. 271-294.

Ginsberg, N.(2005), "The privitisation of council housing," Critical Social Policy, Vol. 25, No. 1, pp.115-135.

Gruis, V. and Nieboer, N. (2003), "Strategic housing management: An asset management model for social landlords," Property Management, Vol.22, No.3, pp. 201-213. 
Hay, G., Beattie, R., Livingstone, R. and Munro, P. (2001)," Change, HRM and the voluntary sector, Employee Relations," Vol. 23, No. 3, pp. 240-255.

Higgs (2003), Review of the role and effectiveness of non-executive directors available at www.dti.gov.uk/cld/non exec review (accessed 3 March 2012)

Holland, T. and Jackson, D. (1998), “ Strengthening Board Performance: Findings and Lessons from Demonstration Projects," NonProfit Management and Leadership, Vol.9, No.2, pp.121-134.

Hough, A. (2006), "In Search of Board Effectiveness," Nonprofit Management and Leadership,Vol.16, No. 3, pp. 373-377.

Huse, M., Nielsen, S. and Hagen, I. (2009), "Women and Employee-Elected Board Members and Their Contributions to Board Control Tasks, " Journal of Business Ethics, Vol. 89, No.4, pp.581-597.

Iles, P., Chuai, X. and Preece, D. (2010), "Talent Management and HRM in Multinational companies in Beijing: Definitions, differences and drivers," Journal of World Business, Vol.45, No. 2, pp. 179-189.

Iles, P. and Preece, D. (2006) "Developing Leaders or Developing Leadership? The Academy of Chief Executive's Programme in the North-East of England", Leadership, Vol. 2, No. 3, pp. 317-340.

Inside Housing (2009), "Board of Appeal" $16^{\text {th }}$ January. Available at www.insidehousing.co.uk/analysis/best-practice/board-of-appeal/6502617.article (accessed 20 March 2012)

Inside Housing (2011), "Strictly boardroom", $4^{\text {th }}$ February. Available at www.insidehousing.co.uk/need-to-know/human-resources/strictlyboardroom/6513524.article (accessed 20 March 2012)

Inside Housing (2011), "Women on top", $11^{\text {th }}$ February. Available at www.insidehousing.co.uk/analysis/supplements/women-in-housing/6513645.article (accessed 9 March 2012)

Inside Housing (2012), "Steering the right course", $3{ }^{\text {rd }}$ February. Available at www.insidehousing.co.uk/regulation/steering-the-right-course/6520279.article (accessed 11 February 2012)

Inside Housing (2012), "Data overload", 13th January. Available at www.insidehousing.co.uk/home/blogs/data-overload/6519921.article (accessed 2 February 2012) 
Jackson, S., Farndale, E. and Kakabadse, A. (2003), "Executive development: meeting the needs of top teams and boards," Journal of Management Development, Vol.22, No.3, pp. 185-265.

Jackson, M. (2010), "Matching rhetoric with reality: The challenge for Third sector involvement in local governance," International Journal of Sociology and Social Policy, Vol.30, Nos. 1/2, pp. 17-31.

Jones, I. and Pollitt, M. (2004), "Understanding how issues in corporate governance develop: Cadbury Report to Higgs Review," Corporate Governance, Vol.12, No. 2, pp.162-170.

Kakabadse, A., Ward, K., Korac-Kakabadse, N. and Bowman, C. (2002), "Role and contribution of non-executive directors," Corporate Governance, Vol. 1, No.1, pp. 4-7.

Kirkpatrick, I., Ackroyd, S. and Walker, R. ( 2005), The New Managerialism and Public Service Professions, Palgrave Macmillan, Basingstoke.

Korac-Kakabadse, N., Kakabadse, A. and Kouzmin, A. (2001). "Board governance and company performance: any correlations?", Corporate Governance, Vol.1, No. 1, pp. 2430.

Long, T. (2008) "Diving for Pearls: The importance of Board Induction and reinduction," International Journal of Business Governance and Ethics, Vol.4, No. 1, pp. 40-50.

McDermont, M. (2007), "Mixed Messages: Housing Associations and Corporate Governance", Social and Legal Studies, Vol. 16, No.1, pp. 71-9.

McNulty, T. and Pettigrew, A. (1999), "Strategies on the board", Organization Studies, Vol. 20, No. 1, pp. 47-74.

Maddock, S. (2002), “ Making modernization work: new narratives, change strategies and people management in the public sector," The International Journal of Public Sector Management, Vol.15, No.1, pp.13-43.

Malpass, P, (2000), "The Discontinuous History of Housing Associations in England. Housing Studies," Vol. 15, No. 2, pp. 195-212.

Mason, C. and Royce, M. (2007), " Fit for Purpose-Board Development for Social Enterprise," Journal of Finance and Management in Public Services, Vol. 6, No. 3, pp5767.

Mawson, J. (2010), "Social enterprise, strategic networks and regional development: The 
West Midlands experience," International Journal of Sociology and Social Policy, Vol.30, No.1/2, pp. 66-83.

Merrett, S. (1979), State Housing in Britain, Routledge London.

Mooney, G. and Poole, L. (2005), "Marginalised voices: resisting the privatization of council housing in Glasgow," Local Economy, Vol. 20, No. 1, pp. 27-39.

Myers, J. (2004), “ Developing managers: a view from the non-profit sector," Journal of European Industrial Training, Vol.28, No.8/9, pp. 639-656.

Oxley, M., Elsinga, M., Haffner, M. and Van der Heijden, H. (2010), "Competition and Social Rented Housing," Housing, Theory and Society, Vol.27, No. 4, pp. 332-350.

Pawson, H. and Mullins, D. (2010), After Council Housing: Britain's New Social Landlords, Basingstoke, Palgrave Macmillan.

Pierce, C. (Ed.) (2001), The Effective Director, Kogan Page, London.

Pollitt, C. (2000), "Is the emperor in his underwear? An analysis of the impacts of public management reform," Public Management, Vol.2, No. 2, pp. 181-199.

Preece, D. and Ward, C. (2012, forthcoming), "Union leadership in UK social housing", Leadership \& Organisational Development Journal, Special Issue.

Preece, D. and Iles, P. (2009) "Executive Development: Assuaging uncertainties through joining a leadership academy", Personnel Review, Vol. 38, No. 3, pp. 286-306

Preston, J. and Brown, W. (2004), "Commitment and Performance of Nonprofit Board Members," Nonprofit Management and Leadership, Vol. 15, No. 2, pp. 221-238.

Pye, A. (2001), "A Study in Studying Corporate Boards Over Time: Looking Backwards to Move Forwards," British Academy of Management, Vol.12, pp. 33-45.

Reid, W. and Turbide, J. (2012), Board/Staff relationships in a Growth Crisis: Implications for Nonprofit Governance," Nonprofit and Voluntary Sector Quarterly, Vol.41, No. 1, pp. 82-99.

Sprigings, N. (2002), “ Delivering Public Services Under the New Public Management: The Case of Public Housing," Public Money and Management, Vol. 22, No. 4, pp. 11-17.

Smith, A. (2010), "The Third Sector, regeneration and sustainable communities,' 'Rolling' with the New Labour agenda,' International Journal of Sociology and Social Policy, Vol.30, Nos.1/2, pp. 48-65. 
Suutari, V. and Viitala, R. (2008), “Management development of senior executives: methods and their effectiveness", Personnel Review, Vol. 37, No.4, pp. 375-392.

Tyson,L. (2003), "The Tyson Report on the Recruitment and Development of NonExecutive Directors," London Business School.

Vicere, A. and Graham, R. (2002), "Crafting Competitiveness: toward a new paradigm for executive development", Human Resource Planning, Vol. 13, No. 4, pp.281-295.

Van der Walt, N., Ingley, C., Shergill, G., and Townsend, A. (2006). "Board Configuration: are diverse boards better?" Corporate Governance, Vol.6, No.2, pp. 129147.

Walker, R. (2001), "How to abolish public housing: implications and lessons from public management reform," Housing Studies, Vol. 16, No. 5, pp. 675-96.

Walker, P. (2009), "A Review of Corporate Governance in UK Banks and other financial industry entities." HM Treasury. Available at http://www.hmtreasury.gov.uk/d/walker_review 261109.pdf. [accessed 3rd March 2012]

Ward, C. and Preece, D. (2010a), 'The changing nature of social housing: a contextual/ processual approach', New Zealand Journal of Human Resource Management, Vol. 10, No.1, pp. 4-12.

Ward, C. and Preece, D. (2010b), "The changing face of UK social housing: some HRM/D implications". Dilemmas for Human Services: Changes and New directions in Human Services, 14th International Research Conference, Lulea University of Technology, September.

Ward, C. and Preece, D. (2010c), "Managership Development?”, $11^{\text {th }}$ International Conference on Human Resource Development Research and Practice across Europe, University of Pecs, Hungary, June.

Ward, C., Blenkinsopp, J. and McCauley-Smith, C. (2010), "Leadership Development in Social Housing: a research agenda", Journal of European Industrial Training, Vol. 34, No. 1, pp. 38-53. 